\title{
Socio-economic Consequences of Development-induced Internal Displacement and the Coping Strategies of Female Victims in Lagos Nigeria: An ethno-demographic Study.
}

\author{
John Lekan Oyefara ${ }^{1}$ and Bamidele Omotunde Alabi ${ }^{2}$ \\ Department of Sociology, \\ Faculty of Social Sciences, \\ University of Lagos, \\ Akoka, Lagos. \\ bamidelalabi@yahoo.com
}

\begin{abstract}
The plethora of violent strife, man-made or natural disasters, economic vicissitudes, and major development schemes have swelled the number refugees and internally displaced people, in the developing countries of the world lately. Statistics revealed that there are over 55 million people in this dire situation globally consisting of over 38 million internally displacedpeople, over 16 million refugees and over 1 million asylum-seekers. This study highlights the impacts, the socio-economic consequences of development-induced internal displacement on females in the Lagos urban space, evaluating the coping strategies employed by them. This is a qualitative study that employed a combination of key informant and in-depth interview methods to generate primary data from the samples purposively drawn from the population of interestwhich comprised people forcibly evicted from Badia, in Lagos State, Nigeria. The interviews were conducted from Tuesday 14th to Thursday 16th October 2014 using unstructured interview guide. The study establishes thatforcible eviction and the consequent displacements brought a myriad of economic, social and psychological hardships on the female victims in Badia, to which they were compelled to devise various ingenious survival and coping strategies. The study ascertains that women cope better emotionally and economically than men in such circumstances and it also found that extended family members are a significant pillar of support to displaced persons.
\end{abstract}

Keywords: Refugees, Internally Displaced Women, Forced Eviction, Impoverishment, Coping Strategies

\section{Introduction}

The number of refugees and internally displaced people in the developing countries of the world is constantly being escalated by the combination of violent strife, man-made or natural disasters, economic vicissitudes, and major development schemes going on in these environments. Reports of the United Nations High Commissioner for Refugees (UNHCR), Global Trends 2014 reveal that almost 60 million people are forcibly displaced globally, consisting of over 19.5 million refugees, 38.2 million internally displaced persons and 1.8 million asylum seekers. Of these statistic, the global overview of the Internal Displacement Monitoring Centre (IDMC) for the year 2014 report that as of the end of 2013, sub-Saharan Africa account for over $32 \%$ of the total number of Internally displaced persons globally, indeed the largest number of 12.5 million, with Nigeria accounting for over 3.3 million of this number.

While the report attributes majority of the incidence of displacement to armed conflict and violence in these areas, displacements induced by 
various development schemes in these environments cannot be discounted. It has been suggested that causes of internal displacement are intricate and can be attributed to environmental change (Terminski, 2011), natural disasters (Kolmannskog \& Afifi, 2014), and development projects (Terminski, 2013), amongst other varying causes. Historically, developmentinduced displacement has been linked with the execution of major policies andprojects which enhances developments, such as construction of dams for hydroelectric power and irrigation, mining, creation of military installations, airports, industrial plants, weapon testing grounds, railways, road developments, conservation projects, forestry, urbanisation and urban renewal (Cernea, 1999;Terminski, 2013). In most developing parts of the world, developmentinduced displacement usually involves the forcible eviction of individuals out of their usual places of abode (Terminski, 2013). As such, it is a social problem that impacts the lives of the people affected. Indeed, it has been noted that approximately fifteen million people each year are forced to leave their homes as a result of big development projects (Cernea, 1995, 2006; Oliver-Smith, 2009; Terminski, 2012).

In effect, development-induced displacements are accompanied by very serious negative social consequences, one of which is economic insecurity,exemplified by loss of means of livelihood, unemployment and limited access to the natural resources on which the people and the communities depend, lack of access to common resources, involuntary relocation and lack of supports, all of which make it difficult to maintain a standard of living, and eventually causing longterm poverty (Aloysius \& Fernandez 2008).According to Cernea (2000) food insecurity, anaftermath of homelessness, landlessness and lack of access to of common resources, is one of the fundamental problems facing displaced people and contributing to their impoverishment. In the same vein, Fernandes and Raj (1992) identified malnutrition as a particularly visible problem among displaced people, mostly girls and women. One of the direct social consequences of displacement which have often been analysed in the literature is deteriorating health conditions (Ramaiah, 1995), and such health risks are often attributed to lack of access to potable water and sanitation, a direct fallout of the progressive deterioration ineconomic conditions, leading to psychological trauma, mental illness and alienation. In particular, children, women and the elderly, whose health situation is worse than that of men even under normal circumstances (Terminski, 2012), have been listed among the categories of people highly vulnerable to health risks associated with development-induced displacement.

According to the UNHCR Global Trends of 2010, women account for a significant number of the world's internally displaced persons. Corroborating this, Cohen et. al. (1998), Fernades, (2007), Ghimire, (2012) and Sandari-Rout, (2012) note that most studies on internal displacement have shown that women constitute a significant proportion of the total internally displaced population and they are known to often be at greater risk than other affected populations, for they face loss of livelihoods, have less access to assistance, and struggle to access adequate education, healthcare, training and livelihoods. Not only that, they also suffer permanent loss of social and cultural ties, the breakdown of their marriages, disruption or loss of educational opportunities for younger ones (Benjamin and Fancy, 1998). In addition, they also face difficulties in exercising rights to housing, land and property, and are often excluded from decision-making processes, and they are found to be more susceptible to emotional, sexual and other genderbased domestic violence, usually exacerbated by an increase in alcoholism, typically backlash of the displacement which is capable of making men feel helpless, insecure and frustrated due to their economic andpsychological inability to sustain the expected gender roles, thereby making them turn women into scapegoats (Ghimire, 2012; Gupta et al, 2009).All of the foregoing is deemed to be capable of causing depression and physical deterioration, which may in turn manifest inposttraumatic stress syndrome (Benjamin \& Fancy, 1998).

Lagos, Nigeria is one place where there have been successive proposals and/or actual executions of different development policies and initiatives, including urban renewal schemes, which have been accompanied by very serious negative social consequences, particularly to women, despite its intended beneficial objectives. A good reference here is the forcible eviction of people from the Badia precinct of Lagos in February 2013, which came with a myriad of these negative aftermaths, particularly for the women caught in the quagmire. Some of these social consequences have been the focus of studies in 
recent times but not much have specifically made the socio-economic impacts of such schemes on women, and how they devise durable strategies to cope with the consequences its main focus. While considerable research focus has been done on internal displacement, not much of such research has been gender-specific. It thus becomes pertinent to investigate the effects of internal displacement, and the coping strategies devised by female victims to deal with it. This study seeks to fill the lacuna in that regard.

The general objective of this paper is to evaluate thecoping strategies of female victims of development-induced internal displacement in the Lagos urban space. Its specific objectives are to:

1. Investigate the socio-economic consequences of internal displacement on female victims.

2. Examine the other impacts of internal displacement on female victims.

3. Interrogate the strategies devised by female victims of internal displacement to cope with their circumstances.

\section{Lagos: A Megacity in the Throes of Slum Development}

Lagos has been classified Lagos as one of the only three megacities in Africa, alongside Cairo and Kinshasa, by the United Nations Population Divisions in its highlights of the 2014 revision of the World Urbanization Prospects (United Nations, 2014). With an estimated population of over 12 million and Ranking $19^{\text {th }}$ in the 2014 global urban agglomeration, the same institution has forecast that Lagos will become the $9^{\text {th }}$ largest city in the world by 2030 , as its population will be over 24 million, growing at an annual rate of 3.9 per cent (United Nations, 2014). The import of these statistics is that not only ispopulation growth in Lagos very rapid, (Abiodun, 1997; Owoade, 2007; Akinmoladun and Oluwoye, 2007; Akiyode, 2012), but that Lagos is also one of the fastest growing cities in the world (UN Populations Division, 2014). With the growth rate projected for the city of Lagos, it goes without saying therefore that the challenges of urban population explosion, such as the development of slums, and shanties and blighted areas, which are already manifest in some areas, will likely continue to escalate. This becomes instructive as already existing data on the development of slums, particularly in Africa has shown that the continent has the largest proportion of people who dwell in the slums and the projection by the United Nations Human
Settlement Programme (UNHSP) is that the global number of slum dwellers will increase to about two billion by 2030 and the largest proportion of them will be in Africa (UNHSP, 2003).

In the Lagos conurbation, slum development is aubiquitous phenomenon and it has at different times received one form ofcorrective or the other. It is on record that the first attempt at regenerating an urban slum by Lagos was in 1929, upon the outbreak of the Bubonic Plague in 1924, after which the then Lagos Executive Development Board (LEDB) was established to undertake a TownPlanning Scheme of the worst affected area, upon which over fifty acres of derelict properties were demolished in Idumagbo, to pave the way for good roads and other amenities (Jimoh, et. al. 2013). Consequently, the Lagos State Government in further attempt to arrest the evergrowing urbansqualor in the state created the Lagos State Urban Renewal Authority (LASURA), an agency under the Ministry of Physical Planning and Urban Development of Lagos State, Nigeria. It was established in 1991 through the Lagos State Edict No. 7 of 1991. The agency was restructured from Lagos State Urban Renewal Board in 2005 vide gazette no. 25 volume 38 of $14^{\text {th }}$ October 2005. To date agency had identified about 75 blighted areas across the state, which have been programmed for renewal (Osatuyi, 2004), and of the areas so marked for renewal, ljora/Badia is one place where people have been evicted as part of the commencementof implementing the renewal schemes.

\section{Literature Review}

Although the effects of displacement precipitated by forcible eviction are generic, it has been established that its consequences on women are more dire than on men (Bartolomé, et. al., 2000; Bonkat, 2014; Segura-Escobar \& Merteens, 1997), particularly in most cases of developmentinduced displacement, where women not only suffer the negative effects more acutely than men do, but also pay the highest prices of displacement, as they are usually the worst hit (Aird, 2001; Terminski, 2012).

In most developing parts of the world, women's interests are not usually incorporated when urban renewal policies and schemes are being formulated and executed. Most often, the execution of such schemes comes with forced eviction, which usually leaves women in dire straits. In such cases, women face a lot of challenges because the negative impacts of such 
initiatives affect them more, as they are known to often be at more prone to the attendant hazards than other affected populations. They lose their source of livelihoods, possess less access to assistance, and struggle to access adequate education, healthcare, and they become vulnerable to series of gender-based violence. Understandably therefore, theeffect of displacement will be more severe on women, particularly in most developing countries like Nigeria. This is because there are already existing gender inequalities, stemming basically fromthe patriarchal natureof such societies, with theirunequal social and political structure, wherethe statutes, policies and processes of the authorities evidently discriminate against women (Hemadri, et al, 1999; Olabisi, 2013).One of the features of the prejudiced socio-political configuration in some of these places is the inability of women to exert rights over productive resources that support livelihood (Parasuraman, 1993).In Nigeria for example, the statutes, deriving from the Land Use Act of 1978, vests exclusive ownership of all land (including every productive resources on it) on the government, which only grants the right to use, develop and occupy the land to citizens at its discretion (Omotola, 1984). Thus, in patriarchal environments like Nigeria, women's interests have typicallybeen underrepresented in policy and planned development, astheir interests are not taken cognisance of during development programmes, particularly where issues of land ownership will come into significance (Olabisi, 2013). As such, in cases of displacement, women have been found to become entirely marginalised (Fernandes, 1996).

Following from these therefore, where there is displacement, women are forced to become dependent on other people because they lose their freedom in social matters, their independence in economic and political matters (Ekka \& Asif, 2000), thereby leading to the decline in the social status of women in the family and society (Pandey, 1998; Patabardhan, 1999).Typically also, women are the first ones to losewhenever there is unemployment arising out of displacement, not just because theylack the skill, but more because as a result of gender bias, they have to make way for the men because in such instances it is always the most eligible male who are selected for jobs, where the jobs are available (Fernandes \& Raj, 1992). This isbecause the female gender is further depressed down the ladder of development by entrenched sociocultural and economic practices that view the female as subordinate to males and therefore reward the females disproportionately (UNDP, 1995), thereby excluding an increasing number of women from active participation in the productive process (Fernandes \& Raj, 1992). However, due to reduced family income as a consequence of displacement, women are burdenedto search for livelihood to add to the household income and thus become unprepared bread winners, thereby getting pushed into in the most exploitative sectors to be engaged as construction, mining and stone workers, domestic services, and agricultural labourers, activities otherwise referred to as the business of men (Bonkat, 2014; Kabeer, 2005). In extreme cases sometimes, the women are forced into prostitution, trafficking and such other vices (Bonkat, 2014).

In cases of deteriorating health conditions, a direct social consequence of displacement (Ramaiah, 1995), women have been found to be the worst affected byincreased morbidity and mortality, as their nutritional and health status goes down proportionately in the event of an overall decrease in the health status (Ekka \& Assif, 1997), caused by lack of access to good food, potable water and sanitation. With regards to sanitation, women are usually the worst hit as the absence of toilet facilities forces them to seek outlet anywhere they can ease themselves (Fernandes \& Raj, 1992), which makes their lives physically uncomfortable and also make them more vulnerable to physical and sexual harassment (Thukral, 1996).

In addition, the upsurge in cases of social vices reflected by alcoholism, prostitution, gambling and theft,consequent to displacements is said to affect directly the lives and status of women by way of violence inflicted on them (Ghimire, 2012; Gupta et al, 2009; Thukral, 1996), as displaced men's psychological feeling of powerlessness usually results into anxiety, idleness and insecurity which tends to cause increase incidence of drinking, wife-beating and domestic violence (Fernandes, 1996; Mehta \&Srinivasan, 1999), in some instances sexual molestation and rape (Best, 2007; Bonkat, 2014).

In the face of dire straits provoked by displacement, the most natural reaction from the victims is usually to device means to assuage their miseries and alleviate their conditions through the process that has been variously referred to as "response", "coping", "survival", or "self-help" 
strategies (Carver et. al., 1989; Jacobsen, 2002; Lazarus, 1966; Vincent, 2001). Often, the need to secure livelihoods becomes one of the most essential steps to deal with displacements. According to Jacobsen (2002), livelihoods concerns how victims of displacement attempt to reduce their economic insecurity, as well as their vulnerability and pursue such steps necessary for survival by accessing and utilizing enabling resources. Such resources, the author suggests, includes social networks and institutions, household assets and social, cultural and economic resources.

Another significant way that displaced persons attempt to deal with their dire circumstances is through alignment with network of friends and family. It has been established that cases of displacement, informal networks of family and friends serve the important function of enhancing access to food, shelter, and basic needs of the victims, since many of them would normally have been forcibly displaced, thereby leaving behind their possessions and sources of livelihood, these networks serve an important function of providinggoods and services to which displaced households would not otherwise have access (ICRC, 2005; Nwaka, 2011). In the same vein, displaced people have also dealt with their situation by aligning with ethnic associations, which have been known to organized networks that serve some important functions, including provision of vital information (Huntington \& Nelson, 1966; Jacobsen, 2002). Indeed, Adetula (2006) posit that the primary goal of these associations is to help members cope with the difficulties of life and as such, belonging to ethnic associations is critical because they provide their members with information about how to access the resources that are available and also support kinsmen through a host of welfare activities.

\section{Theoretical underpinning}

The theories that support and give shape to this work are two-fold: thelmpoverishment Risks and Reconstruction (IRR) model and the Stress and Coping Theory. Made popular by Cernea (1997), the Impoverishment Risks and Reconstruction (IRR) model identified the impoverishment risks inherent in forced eviction and the vital steps to be taken towards reforming the socio-economic lives of the displaced persons. The model emphasised the various negative effects of forced eviction on women in the short and long term. The Stress and Coping Theory as propounded by Lazarus and
Folkman (1984) emphasises the interplay between a person vis-à-vis the context, as well as events within his milieu. It evaluates risks and resilience in the face of adversity while it distinguishes strengths and other protective factors that enable individuals to manage adversity. It highlights how cognitive appraisals of circumstances determine individual emotions, choices, and ultimately response actions.

The theories together provide useful conceptual links used in constructing the methodology of this study, bearing in mind the key issues this research set out to interrogate, which covers the socioeconomic consequences of development-induced displacement on women; and the strategies they adopt for coping with their quandaries. As such, while the Impoverishment Risks and Reconstruction (IRR) model explicitly mirrors the archetypal social consequences of internal displacements induced by most urban renewal schemes in Nigeria and the attendant impoverishment risks which are clearly not atypical of those it proposed, the Stress and Coping Theory highly lends itself to capturing essential aspects of how forced evictions have affected the lives of women in Lagos and how they have attempted to cope with the consequences.

\section{Methods of the study}

This study is qualitative in nature and it employed in-depth interview, a key ethnographic method, to generate primary data from the samples. The samples were purposively drawn from the population of interest (Bernard, 1994), which comprised close to 9,000 people that were forcibly evicted from an estimated 2,237 households, made of about 266 structures that served as homes and business outlets. The sample size was ten persons, because for a study of this nature, smaller but focused samples rather than large samples are often most appropriate (Cassel \& Symon, 1994; Denzin \& Lincon, 2005; Paton, 1990).

The samples were selected randomly, and based on such different purposive characteristics as age, marital and residency status, length of stay in Badia, and most importantly, availability. It is pertinent to mention that only a handful of the displaced people could still be traced within the location and its precinct.

The interviews were conducted by three research assistants from Tuesday 14th to Thursday 16th October 2014. The major instrument employed in eliciting information from 
the interviewees is the unstructured interview guide. Different salient questions were administered, as the interview guide employed was designed to elicit information relevant to the study. The data gathered for this paper were largely qualitative. The data gathered in this study were analysed employing appropriate qualitative data analysis tool. This study followed a careful presentation and meaningful interpretation of data, in such a way that it proffers deep understanding of the subject matter of this paper.

\section{Ethical Issues}

The study observed relevant ethical guidelines and obligations requisite for a research of this nature. Along this line, the interest and welfare of the subjects were taken into consideration in collecting the data. Specifically, the process was carried out in such a manner that ensured that not only the privacy of the interviewees was adequately protected, but also that no real or potential harm or distress, physically or psychologically, came upon the research subjects and care was taken to ensure that they were not put in a compromising position that may expose them to latent or manifest danger. In that vein, no one was asked for name and other identification. In addition, the researchers ensured there were no elements of misrepresentation as the nature and purpose of the research were not concealed from the subjects. Moreover, necessary steps were taken to ensure that personal biases or preconceptions did not influence the conduct and findings of the research.

\section{The Study Location}

The study location is Badia East, Apapa-Iganmu Local Council Development Area of Lagos State. Two distinct communities make up Badia East, namely Oke Ilu Eri and Ajeromi (Lagos State, 2013). The area is located in the southern periphery of the Lagos city. According to Jimohet. al. (2013), Badia East-which is one of the six communities in the axis, namely, Apapa, Badia, Iddo, ljora, Sari-Iganmu, and Panti village-, is a Federal Government acquired area in Lagos State and it was originally taken for overriding public interest. The settlers were thus forced to embark on series of resettlements and as such, title to the land in the places to which they relocated, including Badia East, was never formally transferred to them settlers. In effect, no form of improvement was carried on the land before they started building structures, mainly shanties, and with time the place grew up as settlement.

Therefore, Badia East is an unplanned settlement which lacks basic amenities such as access roads, portable water, sanitary and health facilities, drainages etc. The area was originally a waterlogged and swampy in nature, filled up with refuse and other waste material and acknowledged as a slum, upon which there was a build-up of settlers who erected mostly shanty structures until it grew gradually to become a blighted community. It is an area vulnerable to flooding during rainy season, as a better part of it is known to be flooded for a long time (Jimoh et. al. 2013). Badia East was one of the blighted areas identified by the Lagos State Government for renewal. The renewal exercise commenced with the forcible eviction of the residents in February 2013, by LASURA.

\section{Findings \\ Socio-Demographic Background of Respondents}

In evaluating the coping strategies of female victims of development-induced internal displacement in the Lagos urban space, the study specifically focused on forced eviction of people from Badia East, in February 2013. The women in the study are between the ages 25-66, and these reflect the age characteristic of those who lived in the area. The implication of this is that a majority of them are still in their active and productive phase of life. Except for about three of the interviewees, majority of them were born in the study area and they constitute people in their 30s, making them second-generation settlers, who have known no other community of abode since birth. A majority of the older generation are those who had migrated to and occupied the place since their displacement from "Oluwole", the present site of the National theatre building at Iganmu, thus making them two-time victim of forcible eviction. Majority of the women interviewed did not possess much education as only about 20 per cent reported not having any form of education but merely possess vocational training, while 50 per cent also reported their highest level of education as secondary school, equally combined with vocational training. This explains why most of the women in the area are hair dressers, sex workers, clerks and supervisors in companies, hotels and factories, and petty traders in sachet water, ice blocks, cooked and raw food; soft drinks, beer, kerosene, cooking wood etc. It also explains why 
majority of the interviewees' responses were either in faltering or pidgin English.

\section{Consequences Displacement on the Women}

All the women interviewed did state that forcible eviction had dire consequences for them displaced persons and these include their being rendered homeless and made destitute. Two of the victims asserted thus:

....You can see what the government has done to us now... I no longer have roof over my head and I don't even know where to go from here or who to turn to for help...These people are inhuman and that is why they can do this kind of thing to their fellow human being (IDI, Evictee, 45 years old, Female).

....Being rendered homeless is a recipe for other social problems many of us are going to face which include disintegration of existing social ties, aggravation of such social vices as alcoholism, drug abuse and lack of access to social services and progressive marginalization of the most vulnerable groups such as women and children (IDI, Evictee, 39 years old, Female).

The subjects also took a swipe at the urban renewalpolicies of the government and the existing lopsided social-political structures which are unfavourable to women:

.... The sad part of it all was that nobody here was consulted at anypoint before embarking on this process......Tell me, what kind of government formulates policies that will not take to account theviewpoints of those of us that will be directly affected by their actions(IDI, Evictee,51 years old, Female).

.... They say we are the weaker sex and subordinates us to the men and that's why the social and political structure, the statutes, policies and processes are not always favourable to us.....as you can see in this case we are suffering more than the men (Evictee, 33 years old, Female).

The interviewed women also lamented the loss of means of livelihood, unemployment and lack of access to economic resources which was a direct result of the demolition oftheir houses, shops and different places of business by the government. One of the victims stated that:
.... As you may have found out, almost all of us in this place depend on "our daily bread", which means that we are not salary workers but petty traders and small entrepreneurs...My hairdressing salon was directly in front of my house which has been demolished, meaning that I am not only homeless now but also jobless...ls that not poverty and hunger that is starring me and my family in the face since that is what I depended on to make ends meet (IDI, Evictee, 58 years old, Female).

Another of the victim lamented:

.... I had three machines for grinding pepper and other things and that is what we have depended on to keep the family going since my husband ill health made him lose his job.... Now the machines were destroyed with the kiosk they have demolished.... I don't know how I will be able to get money to send my children to school now.... This is terrible (IDI, Evictee, 51 years old, Female).

Along the same line, an evictee lamented:

.... How would we have got the money to feed ourselves when the exercise has taken away everything from us, including our livelihood, which has led to acute impoverishment, inadequate or outright lack of food, malnourishment and unbalanced diet(Evictee, 42 years old, Female).

The victims bemoaned the consequences of the eviction on the general health condition of the women affected by the exercise. One of the victims asserted thus:

....We were in perfect health in this area before these demolitions exercise because we had access to good water, and our sanitation, particularly in waste disposal were very well...but now, all these are no longer there and you will find that many people around are already experiencing all kinds of health challenges(Evictee, 55 years old, Female).

\section{Another victim noted that:}

....Many people fell ill after they drove us away and people did not have anywhere to go but were sleeping outside. Mosquitoes caused malaria for some, many others suffered from typhoid fever and there was cholera outbreak. During that time, 
an old woman could not survive the trauma .... She died (Evictee, 58 years old, Female).

One other evictee stated thus:

..... Can you begin to count the number of pregnant women that went into forced labour as result of this exercise and how many of them lost their babies in the process...Or is it the women that sunk into depression with series of psychological trauma that caused mental imbalance for some of the women....This is not fair at all (Evictee, 33 years old, Female).

Findings also reveal that another major consequence of displacement on the women is the case of emotional, sexual and other genderbased violenceagainst the female victims. An evictee noted that:

....Another major problem we have is the menace of miscreants who took advantage of the fact that many women have become homeless and decided to molest them sexually every now and then, such that cases of rape against young ladies like me are constantly being reported....Even I almost fell victim but I had to pay my way out of trouble (IDI, Evictee, 21 years old, Female).

One other evictee also stated that:

....Many husbands who are frustrated from the effect of the displacement and have resorted to drinking heavily and in some cases, abuse of Indian hemp and other hard drugs have in turn taken out their frustration on their innocent wives.... You need to see how many women have were beaten almost to a pulp by their husbands (Evictee, 29 years old, Female).

\section{Coping Strategies}

Findings of this study revealed that the affectedwomen were quick brace themselves to the realities of their dire situations and swiftly embarked on conceiving and executing diverse coping strategies and survival mechanisms. In this regard, one of the evictees reacted as follow:

....It has not been easy for me and my family as my husband had to move the family and what is left of our belongings out of here and spread them among families and friends around...I and the childrenhave had to be moving from one relations place to another, at least to be able to sleep(IDI, Evictee, 36 years old, Female).
Another evictee stated that:

.... I will not lie to you, I have been begging to make ends meet and be able to feed myself and my children because the hunger will be too much since my means of livelihood has been taken away by the exercise (Evictee, 58 years old, Female).

As to how the victims have been coping with their situation, one the evictees also reacted thus:

....For how long will I lament, and will lamentation feed me and my family in this situation we have found ourselves.... I now hawk what is left of my stock together with my three teenage children....We take turn to do it and I do my own in the morning until my children return from school, while they pick up their own ...Otherwise, we will just die of hunger (Evictee, 43 years old, Female).

One other evictee stated thus:

.... I will not hide anythingfrom you on this matter at all, I have had to resortto "hustling" (prostitution) to put myself together.... am a widowwith four children to take care of and my kiosk where I sold bags of sachet water was demolished.... I have to use what I have to get what I want (Evictee, 39 years old, Female).

Another evictee stated that:

....In my own case, I just go about to the churches around the Ajegunle neighbourhood to offer myself for sweeping and general cleaning services....It is demeaning for me, but what will I do as I have to pick up the pieces of my life and move on....It does not pay me so well but I get enough to feed me and my five children on a daily basis(Evictee,54 years old, Female).

Regarding their coping strategy for the prevalent health challenges, one of the interviewed victims reacted thus:

.... where is the money for the hospital or to buy drugs when we don't even have any means of livelihood anymore?.... Let me tell you, many of us just take herbs and concoctions to treat ourselves of the different ailments we have been suffering such as malaria, typhoid and cholera (Evictee, 58 years old, Female).

Along the same line, an evictee revealed: 
.... simply just make the medicine myself once I get the necessary herbs together in the right quantity, I simply cook them.... That is what we have been treating ourselves with (Evictee, 34 years old, Female).

As to their coping strategy against cases of emotional, sexual and other gender-based violence, the interviewed victims reacted thus:

....Majority of the rape incidents happen in the night when all these miscreants lay ambush for innocent victims.... simply avoid going out in the night or walking about alone in isolated places, and these days, I combine like three pairs of jeans whenever I want to go out. (Evictee, 23 years old, Female).

Another evictee stated that:

.... have warned my female children to avoid places where they can be attacked because those miscreants are everywhere....Besides, I have also encouraged them to carry sharp objects with them for defence in the event of an attack (Evictee, 56 years old, Female).

One other evictee stated thus:

....When my husband returns drunk, I always know that is when he courts trouble and I do not accede to those antics otherwise the next thing would be for him to start beating me and the children....I avoid any confrontation with him whenever he is in that state.... That is my own strategy of dealing with that situation (Evictee, 56 years old, Female).

\section{Discussion of Findings}

The study did establish that forcible eviction of persons for development reason always leads to the displacement of persons, particularly women, and that such exercises often leave in their trail, series of dire social consequences for the displaced women. All the women interviewed in the course of the research lamented the horrid conditions the inevitable eviction process involved in the implementation of urban renewal schemes in Lagos State put them through.

It will be recalled that Badia East was one of the blighted areas identified by the Lagos State Government for renewal. As such, the eviction process which led to the displacement of the victims was carried out in fulfilling the urban renewal vision of the government to bequeath an enduring modern environment that makes life better; and to facilitate the process of improving the living conditions in blighted areas through upgrading the communities and creating a sustainable environment. The eviction was also as a result of the government's quest to facilitate the process of improving the living conditions of people, upgrading of infrastructural facilities in blighted areas, empowering the communities to create a sustainable environment, and providing decent but affordable housing for the slum dwellers.

The study found that these negative aftermaths of development-induced displacement is often so exacerbated in cases where policies which ultimately inform such exercises were formulated with little or no input from the evictees, particularly women, who are already victims of existing gender inequalities, stemming basically from the patriarchal nature of the Nigerian society, with its unequal social and political structure, where the statutes, policies and processes of the authorities evidently discriminate against women. The subjects in this study did express their despair with the fact that they were neither consulted and neither was their opinion sought in matters of regenerating the environment which directly affects their lives, particularly as women. This finding will seem to support the position of Hemadri, et al. (1999) and Olabisi (2013), the prejudiced socio-political and economic configuration of these societies against women.

The study found that one of the major dire consequences of the exercise which the displaced women face is homelessness. It was also discovered that being rendered homeless was indeed a recipe for other social problems which included disintegration of existing social ties, aggravation of such social vices as alcoholism, drug abuse and lack of access to social services and progressive marginalisation of the women. The subjects confirmed that these were some of the major challenges they faced upon being displaced from their places of abode. These findings indeed validated the standpoint of Agbaje (2013), and Ahiadekeet. al. (1999), that urban renewal programs are regressive mechanism which is elitist in nature, as it forces the poor, whose welfare is short-changed at the altar of political and economic opportunism, to bear the brunt of implementing the schemes, which in many cases result in the destruction of vibrant neighbourhoods. Usually, the aftermath of this has always created additional menace (Theis et.al. 2009) such as destitution, development of more 
shantytowns. The findings further reinforce the opinion of Bogumil (2012) on the social challenges of forced displacements, and also corroborated the Impoverishment Risks and Reconstruction (IRR) model, which, as espoused by Cernea (1997), emphasizing that forced displacement brought about homelessness, amongst other social problems.

Further, the study discovered that the forcible eviction and consequent demolition of houses, shops and different places of business by the government resulted in loss of means of livelihood, unemployment and lack of access to economic resources for the displaced women, the majority of whom were petty traders or people engaged in some vocational occupation, whose business location were most often in close proximity to their places of abode, in most cases having their shops and business outlets usually attached to their houses. The educational profile of the subjects in this study actually predisposed them to the risk the loss of livelihood consequent to displacement. Many of the women were either not educated at all or only barely educated. It was established that the loss of these means of livelihood did have dire economic consequences on the women and it did ultimately cause economic insecurity, which according to Aloysius and Fernandez (2008), is the major social consequence of forcible displacement. These consequences are indeed consistent with some of those identified in the IRR model.

The study discovered that acute impoverishment, typified by inadequate or outright lack of food, malnourishment and unbalanced diet was a major challenge that confronted the women, consequent to the loss of their livelihood. This was not unexpected as the people of Badia East not only lived in the environment but also derived their livelihood from their abode. As such, forcibly taking their abode from them was tantamount to taking away their means of sustenance, and throwing them into acute hunger. This finding echoes the suggestion about food insecurity and malnutrition being part of the fundamental problems displaced people always have to grapple with, and which contributes to their impoverishment (Cernea, 2000; Fernandes and Raj, 1992).

It was further revealed that many of the affected women experienced deteriorating health condition, even one death was reported by the interviewees who attributed their condition to lack of access to potable water, poor sanitation and abysmal waste disposal, amongst other things. The study found that a number of victims experienced acute depression, just as some were on the verge of suffering mental illness, all psychological consequences of displacement made even worse by the distress inherent in the experience, typical of earlier research findings (Ramaiah, 1995) on the health conditions of forcibly displaced persons. Findings also revealed that another major consequence of displacement on the women is the case of emotional, sexual and other gender-based violence against them.

The interviewees reported a number of cases of rape and sexual assault against the women and some of the also reported incidences of domestic violence against the women by their husbands, who most often got dunk out of the frustration of losing their homes, source of livelihood, and essentially, their dignity, and who in turn took out their frustrations on their wives. All of these underscore earlier works (Best, 2007; Bonkat, 2014; Fernandes, 1996; Mehta \&Srinivasan, 1999) on issues of gender based violence perpetrated against displace women.

Furthermore, the study found that rather than mull their circumstances, the women practically rose up to the challenge and fashioned several coping strategies and survival mechanisms (Carver et. al., 1989; Jacobsen, 2002; Lazarus, 1966; Vincent, 2001) to deal with their situation. It was established that some of them had to latch on to their networks and families in their times of distress. Some of the women reported putting up temporarily with friends and relations, while some reported distributing their wards and what was left of their belonging amongst their relations for safekeep. It was also found that some of the women had to resort to hawking, sweeping, begging and even prostituting just to secure their livelihood after displacement. This will seem to underscores Jacobsen (2002), who averred that livelihoods concerns how victims of displacement attempt to reduce their economic insecurity, as well as their vulnerability and pursue such steps necessary for survival by accessing and utilizing enabling resources. Such resources, the author suggests, includes social networks and institutions, household assets and social, cultural and economic resources. The study found that the displaced women also devised other creative strategies to cope with the more severe consequences of displacement. 


\section{Conclusion and Recommendations}

The study set out evaluate the coping strategies of female victims of development-induced internal displacement in the Lagos urban space, the study specifically focused on forced eviction of people from Badia East, in February 2013. The study highlights the socio-economic consequences of internal displacement on female victims.

The actual findings of the research have been detailed and discussed in the preceding paragraphs, and the discussions gave an idea as to the nature and scope of the challenges experienced by displaced women who were forcefully evicted from their homes by the Government of Lagos State, South- West, Nigeria. In-depth interviews were employed to gather data from the field, which enabled the paper focus on the various challenges experienced by the evicted women, which include being rendered homeless, losing their source of livelihood, facing health challenges and also gender-based violence, among others. Some of these women however, devised creative strategies to deal with their circumstances.

Without a doubt, urban renewal initiatives have been adjudged one of the valuable mechanisms that can be deployed as a useful tool to facilitate the upgrade of urban spaces in Nigerian. It is line with this that the government of Lagos State identified some blighted areas within the metropolis to execute the process of renewal. Badia East, with its peculiar history happened to be one of such blighted areas. The displacement of people from this community which was understood to be for overriding public interest, indeed went against the prescribed protections that the people were entitled to, which obligated anygovernment to observe the provisions of applicable human rights laws, and the World Bank's operating policies forbidding forced eviction of people from their usual place of abode, albeit except carried out in accordance acceptable process. In this instance, the absence of specific laws that put a categorical ban on forced evictions, and the absence of statutes that set out the procedural precautions that must be abided by, prior to eviction processes, indeed allowed the for what happened in Badia. In addition, the process appeared to fall short of the globally acceptable good practices as the prescription stipulating that the people should be consulted, carried along, and their input sought through every step of the preparation of the development guide did not hold. Successful urban renewal would easily be achieved when the settlers are carried along. The execution of the renewal scheme in Badia seemed to have been strictly targeted at the physical component of the area while it excluded both the social and economic facet of the place and the people who dwelled therein.

Nonetheless, to achieve a purposeful and effective urban renewal exercise, which can lead to sustainable urban development, the paper therefore recommends that there should be adequate enlightenment of people on the ills of urban decay and the necessity for urban renewal. Following that, all the stakeholders should be involved in the formulation and implementation of policies of urban regeneration. It is also recommended that governments and its agencies should avoid haphazard methods, wherein structures are demolished without putting necessary infrastructures in place. Not only that, governments should give enough time to planning the scheme altogether, in such a way that the implementation will be seamless. Beyond that, proper education as well as orientation should be given to operatives of the governments that have the responsibility of executing the schemes.

In addition, non-governmental entities and media have a duty to assist in the area of sensitization, mobilization and orientation of all the stakeholders in any slum regeneration process. For any renewal scheme, the issue of proper resettlement scheme should not be discountenanced. Adequate compensation of the displaced property owners in the affected areas should be effected. This could involve the provision of alternative low cost housing for the evicted population, and in this regard, theallocation should always be backed with proper documents. Better attention should be placed on such different types of urban renewal as redevelopment, rehabilitation, revitalization and preservation, while policy frameworks which should address statutory and executive powers of implementation by the relevant agencies should be revised. Furthermore, statutes should be revised in ways that will change the already existing gender inequalities and the unequal social and political structure in Nigeria so that the statutes, policies and processes of the authorities evidently will no longer discriminate against women.

\section{References}

Adetula, V. (2005). "Ethnicity and the Dynamics of City Politics: The Case of Jos," in Urban 
African Changing Contours of Survival in the City, eds. Simone, Abdou Maliq and Abouhani, Abdelghani Zed Books Ltd.

Aird, S. (2001).China.s Three Gorges: The Impact of Dam Construction on Emerging Human Rights, Human Rights Brief, American University's Washington College of Law, vol. 8, issue 2 (Winter), pp. 24-37.

Bartolome, L. de Wet, C., Mander, H., Nagraj, V.K. (2000). Displacement, Resettlement, Rehabilitation, Reparation, and Development, WCD Thematic Review I.3 prepared as an input to theWorld Commission on Dams, Cape Town,www.dams.org

Banerjee, P., Sabyasachi C. and Samir K. (eds.). (2005). Internal Displacement in South Asia. Sage Publications, New Delhi.

Berelson, B. (1952). Content analysis in communication research, New York: The Free Press.

Bernard, R. (1994). Research Methods in Anthropology, Qualitative and Quantitative Approaches Alta Mira Press. Walnut Creek.CA.

Best, S.G. (2007). Conflict and Peace Building in Plateau State, Nigeria.Ibadan: Spectrum Books Ltd.

Bonkat, L. (2014). Survival Strategies of Market Women andViolent Conflicts in Jos, Nigeria. Journal of Asia Pacific Studies, November 2014, Volume 3, pp 281-299.

Carver, C., Scheier, V., Michael F, and Weintraub, K. (1989). "Assessing Coping Strategies: A Theoretically Baed Approach," Journal of Personality and Social Psychology. Volume 56, No. 2, Pp 267-283.

Cassell, C. and Symon, G. (Eds) (1994). Qualitative Methods in Organizational Research: A Practical Guide, London, Sage

Cernea, M. (1995). "Social Integration and Population Displacement." In International Social Science Journal, 143/1. Pp 91-112.

Cernea, M. and McDowell, C. (eds.). (2000). Risks and Reconstruction. Experiences of Resettlers and Refugees. The World Bank, Washington D.C.

Cohen, R., and Deng, F. (1998). Masses in Flight, Washington, DC: Brookings Institution Press.

Denzin. N. K., \& Lincoln, Y. S. (2005). The discipline and practice of qualitative research. In N. K. Denzin \& Y. S. Lincoln (Eds.), Handbook of qualitative research (3rd ed., pp. 1-32). Thousand Oaks, CA: Sage.
Ekka, A. and Asif, M. (2000) DevelopmentInduced Displacement and Rehabilitation in Jharkhand, 1951 to 1995: A Database on its Extent and Nature, A Study Supported by Oxfam (India) Trust, Indian Social Institute, New Delhi.

Fernandes, W. (2007)."Development-Induced Displacement: The Class and Gender Perspective", Paper presented at the International Conference on The Emerging Woman in the Indian Economy. Christ College, Bangalore.

Fernandes, W. and S. Anthony Raj (1992) Development, displacement and Rehabilitation in the Tribal Areas of Orissa, Indian Social Institute, New Delhi.

Haug, R. (2003). What's in a Name: Environmental Refugees in Sudan. N. Shanmugaratnam, Ragnhild Lund \& KristianneStølen (eds.) In the Maze of Displacement. Conflict, Migration and Change, Høyskoleforlaget, Kristiansand, pp156-176.

Hemadri, R., Samiti, B., Mander, H. \& Nagaraj, V. (1999). Dams, displacement, policyand law in India, report prepared for the World Commission on Dams, available online at http://www.dams.org/docs/kbase/contrib/soc21 3.pdf

Holsti, O.R. (1968). Content Analysis. In G.Lindzey \&E. Aronson (Eds.), The Handbook of Social Psychology (2nd ed.) (Pp.596-692), Vol.II, New Delhi: Amerind Publishing Co.

Huntington, S., and Nelson, J. (1976). No Easy Choice: Political Participation in Developing Countries Harvard University Press.

International Committee of the Red Cross (2005). IDPs in Colombia: A Joint Needs Assessment $B y$ the ICRC and the World Food Programme.

Jacobsen, K. (2002). "Livelihoods in Conflict: The Pursuit of Livelihoods by Refugees and the Impact onthe Human Security of Host Communities." International Migration Volume 40, Number 5, Special Issue 2, (2002): 95-123 Accessed from http://www.blackwellsynergy.com/doi/pdf/10.11 11/1468-2435.00213\#article

Jimoh, H., Omole, F., Omosulu, S. (2013). An examination of urban renewal exercise of Badia East of Lagos State, Nigeria. International Journal of Education and Research Vol. 1 No. 5. Pp 1-14.

Kabeer, N. (2005). Gender Mainstreaming in Poverty Eradication and the Millennium Development Goals: A handbook for policy- 
makers and other stakeholders. New Gender Mainstreaming Series on Development.

Kerlinger, F.N. (1986). Foundations of behavioural research (3rd ed), New York: Holt, Rinehart and Winston.

Kolmannskog, V and Afifi, T (2014). DisasterRelated Displacement from the Horn of Africa Report No.15. Bonn: United Nations University Institute for Environment and Human Security (UNU-EHS).

Lazarus, R. (1966). Psychological stress and the coping process. New York: McGraw-Hill (1966).

Lazarus, R., and Folkman, S. (1984). Stress, appraisal, and coping. New York, NY: Springer.

Lund, R. (2003). Representations of Forced Migration in Conflicting Spaces: Displacement of the Veddas in Sri Lanka. In the Maze of Displacement. Conflict, Migration and Change.Høyskoleforlaget, pp.76-104.

Muggah, R. (2003). A Tale of Two Solitudes: Comparing Conflict and Development-Induced Dispalcement and Involuntary Resettlement. International Migration Vol. 41, No5: pp. 5-31.

Nwaka. J. C (2011): Biafran Women and the Nigerian Civil War: Challenges and Survival Strategies in Africa Peace and Conflict Journal Vol 4 No 1. 34-46.

Olabisi, Y. (2013). "Gender Issue and Urban Renewal Development: An Examination of Challenges of Evicted Market Women in Lagos State, Nigeria."American Journal of Rural Development 1.2 (2013): 19-25.

Osatuyi, J. (2004). Challenges of Urban Decay in Lagos State: A Case Study of Agege/lfako ljaiye Local Government Areas. A MURP Dissertation Submitted to the Department of Urban and Regional Planning, Lagos State University, Ojo, Lagos, Nigeria.

Pandey, B. (1998). Depriving the Underprivileged for Development. Bhubaneswar, India: Institute for Socio-Economic Development.

Parasuraman, S. (1993). Impact of Displacement by Development Projects on Women in India, Working Paper Series No. 159, Institute of Social Studies, The Hague, August.
Patabardhan, A. (1999) Dams and Tribal People in India, Contributing Paper for World Commission on Dams, Thematic Review 1.2 Dams and Indigenous People and Vulnerable Ethnic Minorities.

Patton, M. (1990). Qualitative evaluation and research methods (pp. 169-186). Beverly Hills, CA: Sage.

Polkinghorne, D. (1983). Methodology for the human sciences. Albany, NY: Human Sciences Press.

Qadeem, M. (2005). Afghanistan: The Long Way Home. Paula Banerjee, Sabyasachi Basu Ray

Chaudhury and Samir Kumar Das (eds.). 2005. Internal Displacement in South Asia. Sage Publications, New Delhi, pp, 30-61.

Sundari-Rout S. (2012) Development induced Displacement and the Indigenous Societies in India: Understanding Displacement Impacts from Gender Perspectives. Lambert Academic Publishing.

Segura- Escobar, N. and Meertens, D (1997).Up rootedness, Gender and Internal Displacement in Colombia, Beyond Law, Vol. 6, Issue 17, January 1997.

Terminski, B. (2011). Environmentally-Induced Displacement. Theoretical Frameworks and Current Challenges, CEDEM Working Paper, Universite de Ličge,

Terminski, B. (2013). Development-Induced Displacement and Resettlement: Social Problem and Human Rights Issue. University of Geneva Research Paper No. 9

Thukral,.G. (1989). Dams: For Whose Development? in Walter Fernandes and E.G. Thukral (eds) Development, Displacement and Rehabilitation, Indian Social Institute, New Delhi.

United Nations Human Settlement Programme (UNHSP)(2003)."Facing the Slum Challenge" Global Report on Human Settlements. Advanced Draft Report. UN-Habitat, Nairobi.

Vincent, M. (2001). "Response Strategies: The Need to Involve the Displaced." In Norwegian Refugee Council Response Strategies of the Internally Displaced: Changing the Humanitarian Lens Reportof a Seminar held in Oslo, Norway. 